Gut, 1987, 28, S1, 165-168

\title{
Proximal enterectomy provides a stronger systemic stimulus to intestinal adaptation than distal enterectomy
}

\author{
G V N APPLETON, J B BRISTOL, AND R C N WILLIAMSON \\ From the University Department of Surgery, Bristol Royal Infirmary, Bristol
}

SUMMARY Enteroglucagon has been implicated as a tropic hormone in the control of intestinal adaptation. Because cells producing enteroglucagon are located mainly in the distal small bowel (and colon), ileal resection might be expected to produce less adaptive change than a jejunal resection of equivalent length. This hypothesis was tested in male Sprague-Dawley rats $(\mathrm{n}=40)$ weighing $184.0 \pm 7 \cdot 3 \mathrm{~g}$ and receiving a Thiry-Vella fistula (TVF) of the mid-60\% of the small intestine. One group had concomitant resection of the jejunum proximal to the TVF $(n=12)$, another had resection of the ileum distal to the TVF $(n=13)$, while controls had a TVF alone $(n=15)$. When killed 10 days postoperatively rats with ileal resection weighed only $81 \%$ of controls $(p<0.001)$ and $85 \%$ of those with jejunal resection $(\mathrm{p}<0.01)$. Jejunal resection produced an $81 \%$ increase in crypt cell production rate (measured by a stathmokinetic technique) over control values $(28 \cdot 5 \pm 4 \cdot 2 v$ $15 \cdot 8 \pm 2 \cdot 3$ cells/crypt/h: $\mathrm{p}=0.025)$, whereas ileal resection had no demonstrable effect $(17 \cdot 5 \pm 2 \cdot 3$ cells/crypt/h). Adaptive hyperplasia in isolated small bowel is modulated by factors localised to the distal small intestine, enteroglucagon being a plausible candidate.

Although the phenomenon of intestinal adaptation has been recognised for a century, ${ }^{1}$ it was not until the 1960 's that serious consideration was given to the mechanisms governing compensatory hyperplasia. Loran and Crocker $^{2}$ proposed the existence of an 'intestinal epithelial growth hormone', whereas Dowling and Booth ${ }^{3}$ underlined the paramount importance of luminal nutrition. There now seems little doubt that humoral agents are involved, being secreted in response to luminal chyme. We have previously ${ }^{1}$ summarised the data that implicate systemic agents, including the detection of a modest compensatory response in isolated loops of bowel ${ }^{4}$ or parabiotic partners of rats with resection. ${ }^{5}$

On present knowledge the most plausible single candidate for the role of an 'enterotropin' is enteroglucagon. Certainly plasma concentrations of enteroglucagon closely parallel ileal crypt cell production rate in several models of adaptation including small bowel resection, ${ }^{67}$ hypothermia, ${ }^{6}$ lactation ${ }^{8}$ and intravenous feeding. ${ }^{6}$ Moreover one patient with an enteroglucagonoma had dramatic intestinal hyper-

Address for correspondence: Professor R C N Williamson, Department of Surgery, Bristol Royal Infirmary, Bristol BS2 8HW. plasia that disappeared after resection of the tumour. ${ }^{9}$

As enteroglucagon is found in greatest concentration in the distal ileum (and colon), ${ }^{10}$ we have compared the adaptive potential of jejunal and ileal resections in loops of mid-small bowel isolated as a Thiry-Vella fistula.

\section{Methods}

ANIMALS

Fifty male Sprague-Dawley rats (Olac Ltd, Bicester) weighing $180 \pm 7 \cdot 3 \mathrm{~g}$ were submitted to laparotomy under light ether anaesthesia. In each animal a ThiryVella fistula (TVF) was created by isolating the mid$60 \%$ of the jejunoileum and exteriorising each end as a mucous fistula. This length of fistula was chosen after a pilot study had shown that shorter TVFs were often associated with atrophy or necrosis of the loop.

Rats were randomly allocated to one of three groups. Controls had no further operative procedure, intestinal continuity being directly restored by end-toend jejunoileal anastomosis (Fig. 1). The other groups 

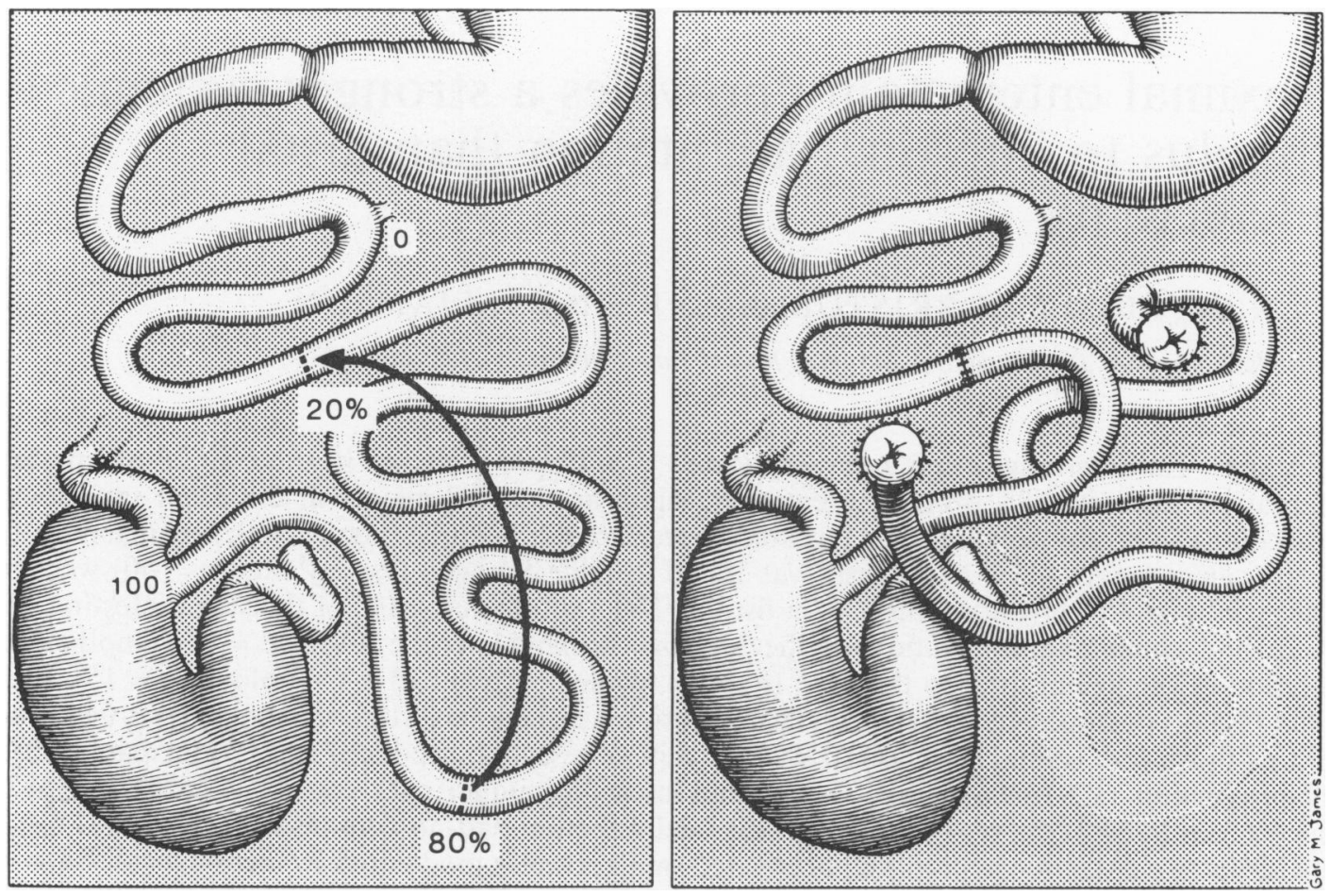

Fig. 1 Creation of a Thiry-Vella fistula from the mid $60 \%$ of the jejunoileum.
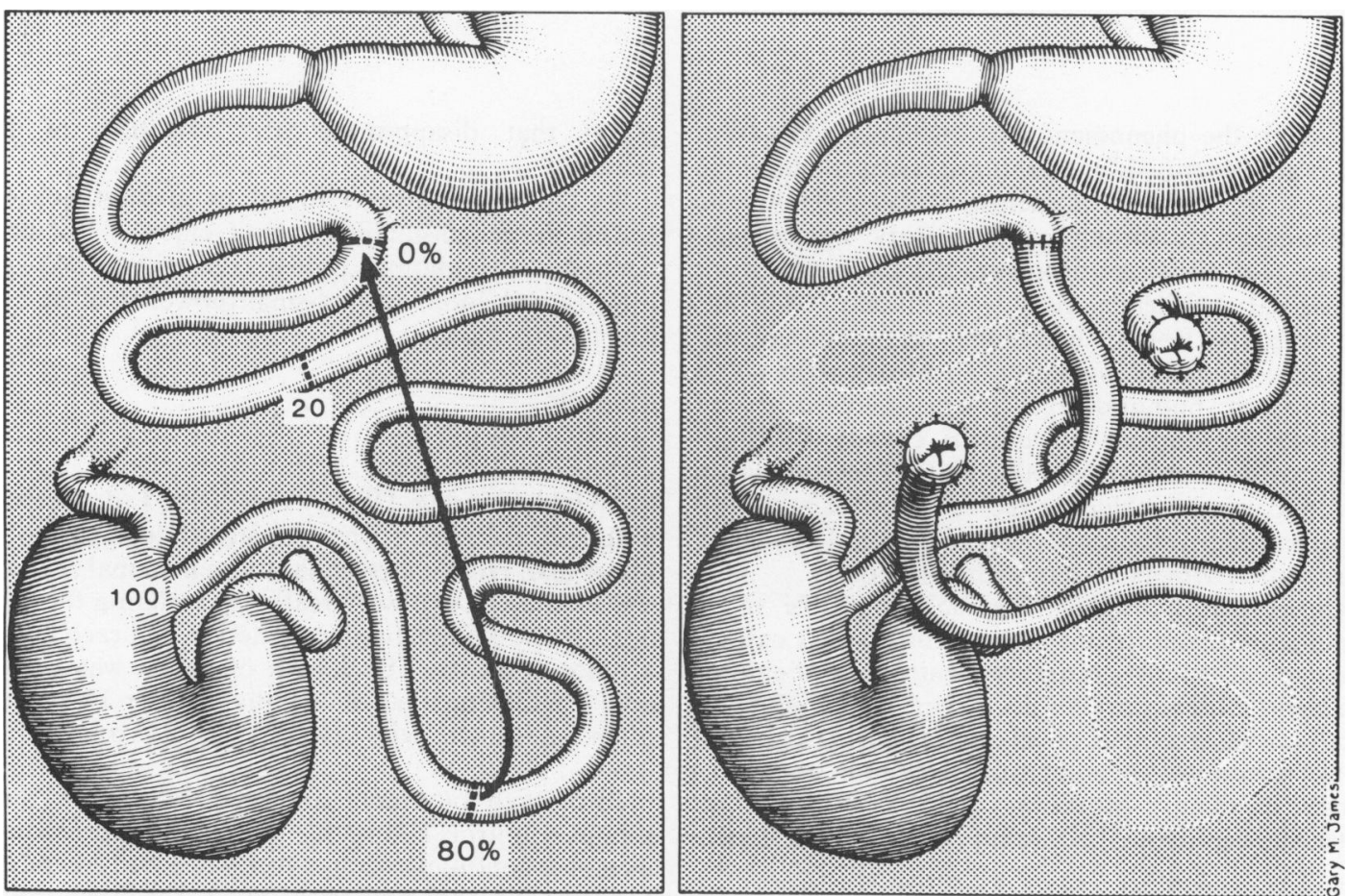

Fig. 2 Creation of a Thiry-Vella fistula plus $20 \%$ proximal small bowel resection. 

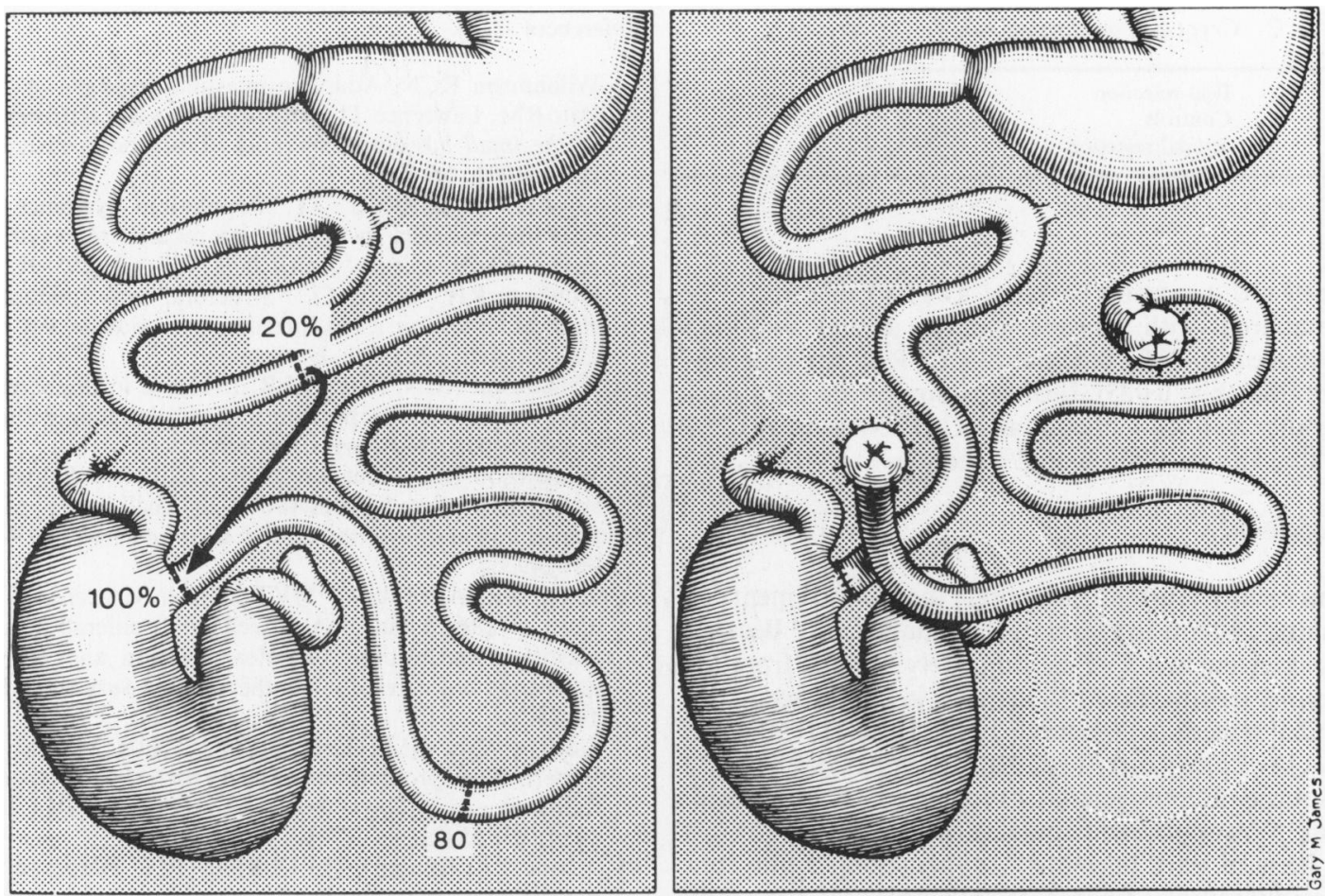

Fig. 3 Creation of a Thiry-Vella fistula plus $20 \%$ distal small bowel resection.

had a $20 \%$ small bowel resection in addition to TVF. Rats with jejunal resection had all jejunum proximal to the TVF excised, with anastomosis between the duodendojejunal flexure and distal ileum (Fig. 2). Rats with ileal resection had all ileum distal to the TVF resected, with anastomosis between the proximal jejunum and ileocaecal junction (Fig. 3). All intestinal anastomoses were created using a continuous $6 / 0$ silk suture. The two stomas were sutured to the skin with interrupted $6 / 0$ catgut on either side of the midline laparotomy incision. Each rat received an im injection of vitamin $\mathrm{K} 0.25 \mathrm{mg} / \mathrm{kg}$ at the end of the operation to prevent postoperative bleeding.

Ten days postoperatively rats were weighed and then were killed at intervals $40-180$ minutes after ip injection of vincristine sulphate (Oncovin, Eli Lilly, Basingstoke) $1 \mathrm{mg} / \mathrm{kg}$ which was given to bring about metaphase arrest within the intestinal crypts. ${ }^{11} \mathrm{~A}$ small segment of bowel obtained from the centre of the TVF was fixed in Carnoy's fluid for four hours, then stored in $70 \%$ alcohol. Bowel samples were stained by the Feulgen reaction for DNA, the mucosa was stripped off the muscle coat and metaphase figures were counted in 10 individually microdissected crypts per specimen. ${ }^{12}$ The mean number of metaphase arrests was plotted against time after vincristine administration, and crypt cell production rate (CCPR) was calculated by linear regression analysis. ${ }^{11}$

Ten animals were lost to analysis because of premature death $(n=6)$ or because the TVF was unusable.

Statistical significance was assessed using Student's $t$ test for unpaired data.

\section{Results}

BODY WEIGHT (Table 1)

Controls with TVF alone gained $20 \%$ in weight over the 10 days of the experiment. Rats with jejunal resection also gained weight (by $14 \%$ overall), but rats with ileal resection remained at a similar weight to the preoperative value.

Table 1 Weight 10 days postoperatively ( $\mathrm{g}$ )

$\begin{array}{ll}\text { Ileal resection } & 178 \cdot 4 \pm 12 \cdot 3^{*} \\ \text { Controls } & 221.4 \pm 14 \cdot 6 \\ \text { Jejunal resection } & 209 \cdot 2 \pm 13.9\end{array}$

${ }^{*} \mathrm{p}=0.0001 v$ controls; $\mathrm{p}=0.008 v$ jejunal resection 
Table 2 Crypt cell production rate (cells/crypt/h)

\begin{tabular}{ll}
\hline Ileal resection & $17 \cdot 5 \pm 2 \cdot 3$ \\
Controls & $15 \cdot 8 \pm 2 \cdot 3$ \\
Jejunal resection & $28 \cdot 5 \pm 4 \cdot 2^{*}$ \\
\hline
\end{tabular}

${ }^{*} p=0.025$

CRYPT CELl PRODUCTION RATE (Table 2)

Compared with control values, jejunal resection produced an $81 \%$ increase in CCPR in the centre of the TVF $(p=0.025)$. Ileal resection produced a nonsignificant $17 \%$ increase, and CCPR was only $62 \%$ of that in rats with jejunal resection.

\section{Discussion}

This study further supports the involvement of humoral agents in the control of adaptation. ${ }^{4}$ Because the intestine in a TVF is completely isolated from the luminal stream, the $81 \%$ increase in CCPR seen after jejunal resection must surely be mediated systemically. We have also confirmed that an enhanced adaptive response follows jejunal as opposed to ileal resection, ${ }^{1313}$ and it seems that the explanation for this is at least in part hormonal. Hyperaemia might conceivably cause compensatory hyperplasia ${ }^{14}$ but would seem unlikely to explain the marked response in CCPR to a limited $(20 \%)$ resection of the small bowel.

Enteroglucagon is produced mainly in the distal ileum (and colon). ${ }^{10}$ Tissue levels are much higher at this site than in the jejunum and rise still further after partial resection. ${ }^{8} \mathrm{~A}$ tropic role for enteroglucagon has been postulated in both man and animals. ${ }^{615} \mathrm{It}$ is thus possible that increased release of enteroglucagon from the remaining ileum of rats with jejunal resection stimulates hyperplasia within the TVF. This stimulus would have been much lower after ileal resection, as this removes the major source of enteroglucagon. Alternatively an antitropic substance present in the proximal bowel is removed by jejunal resection but still present after ileal resection. Somatostatin is found in decreasing amounts from jejunum to ileum ${ }^{16}$ and infusions of this peptide prevent postresectional ileal hyperplasia. ${ }^{16}$ Doubtless the situation is complex, as somatostatin inhibits various gastrointestinal functions (including enteroglucagon release), ${ }^{15}$ and other potentially tropic hormones such as neurotensin ${ }^{10}$ and bombesin ${ }^{15}$ could also be involved. It is entirely logical that any substance controlling adaptation of the small intestine should reside distally. At that site alterations in chyme are maximal after resection and it is presumably these alterations that initiate the release of humoral agents.

\section{References}

1 Williamson RCN. Adaptive intestinal hyperplasia. In: Batt RM, Lawrence TLJ, eds. Function and dysfunction of the small intestine. Liverpool: Liverpool University Press, 1984: 55-76.

2 Loran MR, Crocker TT. Population dynamics of intestinal epithelia in the rat two months after partial resection of the ileum. J Cell Biol 1963; 19: 285-91.

3 Dowling RH, Booth CC. Structural and functional changes following small intestinal resection in the rat. Clin Sci 1967; 32: 139-49.

4 Williamson RCN, Bauer FLR. Evidence for an enterotopic hormone: compensatory hyperplasia in defunctioned bowel. Br J Surg 1978; 65: 736-9.

5 Williamson RCN, Buchholtz TW, Malt RA. Humoral stimulation of cell proliferation in small bowel after transection and resection in rats. Gastroenterology 1978; 75: 249-54.

6 Sagor GR, Al-Mukhtar MYT, Ghatei MA, et al. The effect of altered nutrition on cellular proliferation and plasma concentrations of enteroglucagon and gastrin after small bowel resection in the rat. BrJ Surg 1982; 69: 14-18.

7 Gornacz GE, Al-Mukhtar MYT, Ghatei MA, et al. Pattern of cell proliferation and enteroglucagon response following small bowel resection in the rat. Digestion 1984; 29 : 65-72.

8 Jacobs LR, Bloom SR, Dowling RH. Response of plasma and tissue levels of enteroglucagon immunoreactivity to intestinal resection, lactation, and hyperphagia. Life Sci 1981; 29: 2003-7.

9 Gleeson MH, Bloom SR, Polak JM, et al. Endocrine tumour in kidney affecting small bowel structure, motility, and absorptive function. Gut 1971; 12: 77382.

10 Bloom SR. Gut and brain-endocrine connections. The Goulstonian Lecture 1979. J R Coll Phys (Lond) 1980; 14: 51-7.

11 Wright NA, Appleton DR. The metaphase arrest technique - a critical review. Cell Tissue Kinet 1980; 13: 643-63.

12 Goodlad RA, Wright NA. Quantitative studies on epithelial replacement in the gut. In: Titchen DA, ed. Techniques in digestive physiology Dublin: Elsevier Scientific Publishers Ireland Ltd, 1982: 1-23.

13 Bristol JB, Williamson RCN. Postoperative adaptation of the small intestine. World J Surg 1985; 9: 825-32.

14 Touloukian RJ, Spencer RP. Ileal blood flow preceding compensatory intestinal hypertrophy. Ann Surg 1972; 175: $320-5$.

15 Sagor GR, Ghatei MA, O'Shaughnessy DJ, et al. Influence of somatostatin and bombesin on plasma enteroglucagon and cell proliferation after intestinal resection in the rat. Gut 1985; 26: 89-94.

16 Holmes SJK, Jaspan JB, Moossa AR. The effect of somatostatin on postresectional ileal hyperplasia. Endocrinology 1982; 111: 1397-9. 